\title{
Anthropogenic Impacts on Karst example of Lusaka
}

\author{
Robert Kayombo ${ }^{1}$, Svetlana E. Mazina ${ }^{1,2, *}$ \\ ${ }^{1}$ Peoples Friendship University of Russia (RUDN University), Faculty of Ecology, 6 Miklukho- \\ Maklaya Street, Moscow, 117198, Russian Federation \\ ${ }^{2}$ Moscow State University M.V. Lomonosov, Faculty of Chemistry, 119991 Moscow, Russia
}

\begin{abstract}
A study was aimed at assessing the anthropogenic impacts on Karst water in Lusaka's Chainda peri-urban area on the quality of groundwater by physical, chemical and microbiological indicators. It was observed that concentrations of the Total and Faecal Coliforms in all the samples from the shallow wells and private boreholes were all above the Zambia Bureau of Standards. In terms of bacteriological quality, the water used for consumption in Chainda is poor. This poses great danger to human health. $\mathrm{pH}$ values of all the samples tested were within the Zambia Bureau of Standards. The study also revealed that the karst water in Chainda is high in nitrates due to lack of sanitation facilities. Nitrates concentration were above the Zambian Bureau of Standards of $10 \mathrm{mg} / \mathrm{l}$ in all the shallow wells and private boreholes. While nitrate concentrations in water kiosks of LWSC are below ZABS.
\end{abstract}

\section{Introduction}

Karst and caves have a high cultural and historical value, karst regions are spread all over the world [1]. Of particular importance are karst massifs as areas where the accumulation of karst water, its transportation and self-cleaning occurs [2]. Actual problems of accumulation of pollutants in karst cavities and the decline in the quality of karst water [3], the development of methods for cleaning underground reservoirs [4], the study of the features of karst ecosystems [5].

In some regions, problems with water supply make it necessary to consider karst waters as the best source of water supply, especially according to the criteria of constancy and water quality, one of these regions is Lusaka [6]. The city of Lusaka is built on a plateau that is located at an altitude of $1300 \mathrm{~m}$ above sea level to the north and gradually descends to $1200 \mathrm{~m}$ above sea level to the east, south and west [7]. Bäumle and coauthors [8] noted that the flat morphology of the Lusaka plateau is the result of intense and prolonged weathering of exposed lithologies, resulting in flat shale and carbonate plains with rounded quartzite hills forming a huge erosional plateau known as the surface of Gondwana and Africa [9].

\footnotetext{
${ }^{*}$ Corresponding author: conophytum@mail.ru
} 
Historically, the area of Lusaka produced charcoal, there was intensive agriculture, there was mining (limestone, dolomite), there were frequent seasonal fires. Intensive economic activity in the Lusaka area has led to degradation of the natural terrain, changes in vegetation, pollution of surface waters and increased anthropogenic impact on groundwater and karst landscapes, including due to increased urbanization [7].

The epicarst zone of the Lusaka dolomite marble formation is covered with a layer of continental soil, the thickness of which can reach several meters [10].

Laterite, consisting of oolites embedded in a clay matrix, acts as a shield for pollutants to enter directly into the aquifer, but it is constantly eroded by laterite quarries [11].

The problem is complicated by the presence of permanent contamination of ground water from waste pits, due to their ingress and rapid spread in underground waters [11].

The problem is complicated by the presence of permanent contamination of ground water from waste pits, due to the ingress of sewage and the rapid spread of pollution in underground waters. Liquid waste and waste water accumulate in open channels or in cesspools without waterproofing, solid urban waste is randomly dumped into open spaces between houses or taken to illegal landfills.

Therefore, it is important to assess the quality of groundwater by physical, chemical and microbiological indicators and to develop recommendations for the preservation of water quality, removal of pollution and restoration of karst sources.

\section{Methodology}

The water sampling was done in Chainda a peri-urban settlement of Lusaka. The sampling was conducted between the month of January 2020 and February 2020. The area was first surveyed and later three points were randomly selected. Sampling point A (shallow well) was set at house number Z4/13, sampling point B (Private Borehole) was at house number S3/19 and last sampling point C (Water Kiosk by Lusaka Water and Sewerage Company) was set at Plot 8286. A total of 18 samples were collected. These samples were tested for $\mathrm{pH}$, Total Coliforms, Escherichia coli and Nitrates at the Lusaka Water and Sewerage laboratory in Kafue.

\section{Results and discussion}

\section{$3.1 \mathrm{pH}$ level}

The $\mathrm{pH}$ levels from all the 18 water samples were within the allowable limits of the Zambia Bureau of Standards (ZABS) and World Health Organization (WHO). Figure 1 below shows the results of the $\mathrm{pH}$ tests carried out from the sampling points.

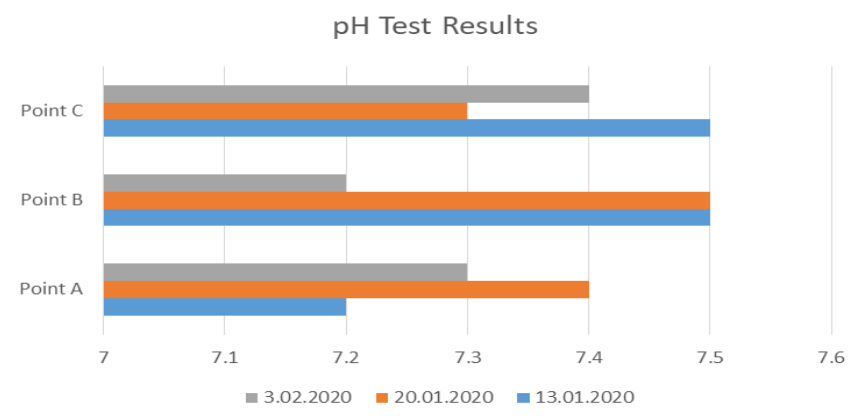

Fig. 1. $\mathrm{pH}$ test results. 
The Lusaka Karst water is general very low concentrations of dissolved constituents (Total dissolved solids concentrations are less than 200mg/1 [11]. This may explain why the $\mathrm{pH}$ values for the study are mostly above 7 slightly.

\subsection{Total Coliforms}

The results indicates that all samples from point $\mathrm{A}$ and $\mathrm{B}$ had concetrations of Total Coliforms above the ZABS limit, as they were all above the $20 \mathrm{CFU} / 100 \mathrm{ml}$ limit. Whereas as water samples from point $\mathrm{C}$ were below the Zambia Bureau of Standards (Fig. 2).

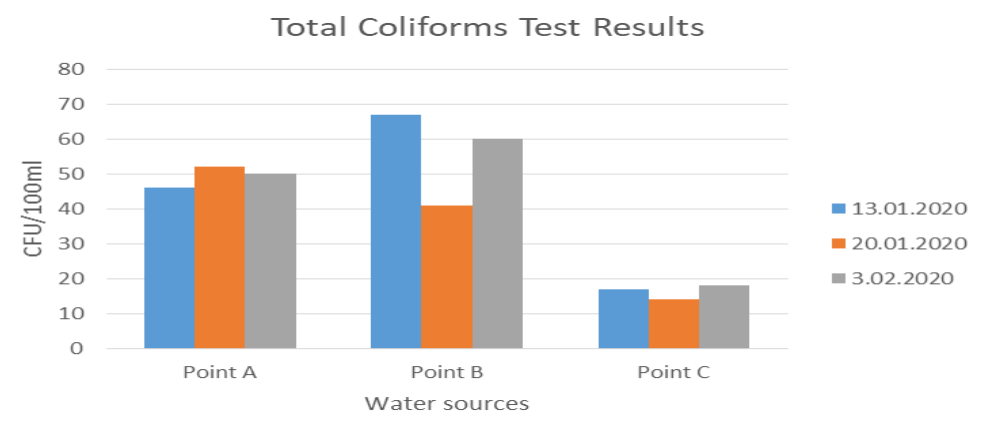

Fig. 2. Total Coliform test results.

The high concentration levels of Total Coliforms in the water samples maybe as a result of anthropogenic activities in the areas such as poor sanitation. Other sources of total coliforms can be faeces of warm-blooded animals, soils, and plants. It was observed by Manafi [12] that a total coliform results does not necessarily prove that the water is contaminated with pathogens. However, a higher MPN (Most probable Number, as a measure of concetration for Bacteria) as high as 500 should be regarded as an alarming sign for feacal contamination. Microbiological contamination also suggest the influence of human activities on the quality of groundwater.

\subsection{Faecal Coliforms}

The water water samples from the swallow wells (Point A) and private boreholes (Point B) were all above the allowable limits of Zambia Bureau of Standards. The study didnt find anyE coli in (Water Kiosks) Point C (Fig. 3). The standards dictates that water for drinking should not contain any Faecal coliforms.

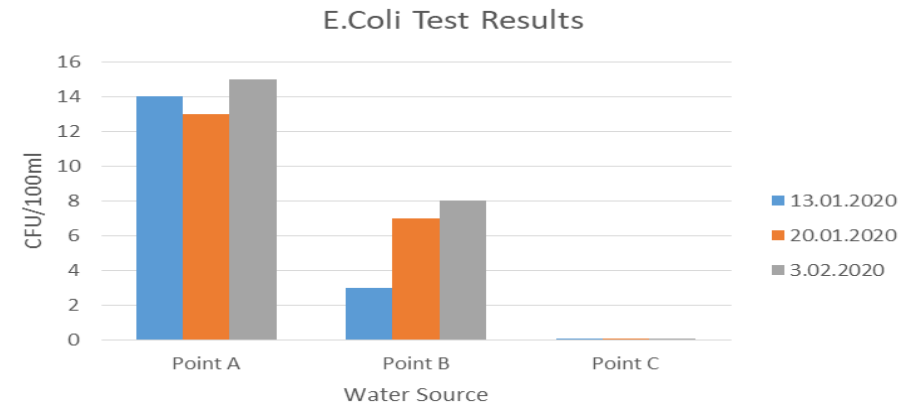

Fig. 3. Escherichia coli test results. 
The presence of faecal coliforms in aquatic environments may indicate that the water has been contaminated with the faecal material of humans as observed from the samples. The presence of of $E$. coli in swallow wells and private borehores maybe attributed that the fact that the residents of Chainda like other peri-urban areas have no proper sanitation, they use mostly pit-latrines for excreta disposal and have no proper waste disposal. The pitlatrines are poorly constructed without any lining and are close to water sources due to lak of yard space. Excreta disposal in the pit-latrines may result in contaminant and nutrient loads that can eventually enter water supplies such as wells and boreholes.

\subsection{Nitrate}

The study revealed that shallow wells (Point A) and private boreholes (Point B) have nitrate concentrations above the ZABS limit for drinking water, whereas point $\mathrm{C}$ (Water Kiosks) are below the limit. Water kiosks had an average of $9.3 \mathrm{mg} / \mathrm{l}$ (Table 1, Fig. 4). This is cause because the area is served by pit latrines and septic tanks. In Chainda and other peri-urban areas of Lusaka have the high nitrate loads caused by their overall poor sanitary situation.

Table 1. Shows the average Nitrate concentrations of the water samples

\begin{tabular}{|l|c|c|c|c|}
\hline Date & Point A, $\mathrm{mg} / \mathrm{l}$ & Point B, $\mathrm{mg} / \mathrm{l}$ & Point C, $\mathrm{mg} / \mathrm{l}$ & ZABS max $\mathrm{mg} / \mathrm{l}$ \\
\hline $\mathbf{1 3 . 0 1 . 2 0 2 0}$ & 15 & 13 & 9 & 10 \\
\hline $\mathbf{2 0 . 0 1 . 2 0 2 0}$ & 21 & 12 & 11 & 10 \\
\hline $\mathbf{0 3 . 0 2 . 2 0 2 0}$ & 19 & 16 & 8 & 10 \\
\hline
\end{tabular}

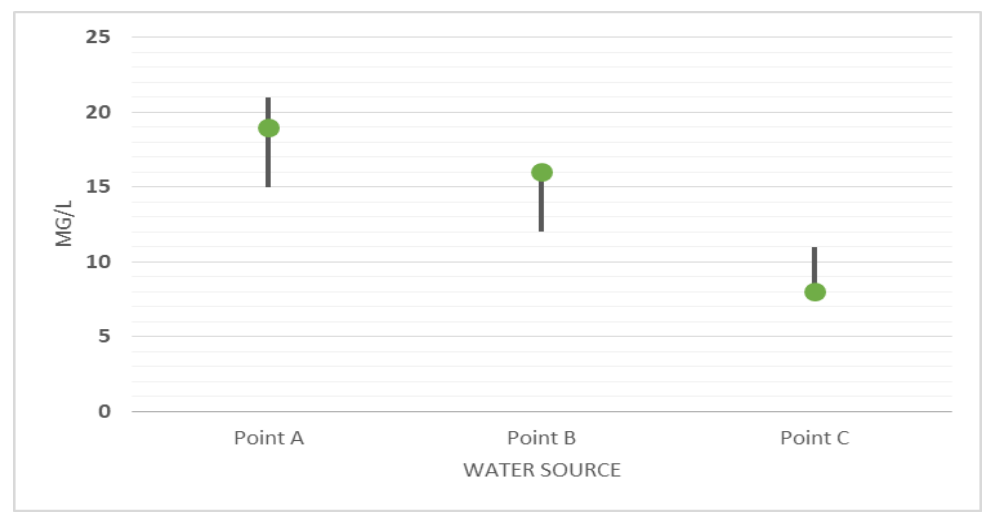

Fig. 4. Average Nitrate Concentrations in the water samples.

Nitrate pollution is an indicator of faecal contamination of the local water supply in perurban areas such as Chainda in Lusaka.

\section{Conclusion}

According to the findings, it was observed that concentrations of the Total and Faecal Coliforms in all the samples from the shallow wells and private boreholes were all above the Zambia Bureau of Standards. In terms of bacteriological quality, the water used for consumption in Chainda is poor. This poses great danger to human health. $\mathrm{pH}$ values of all the samples tested were within the Zambia Bureau of Standards and World Health Organization guidelines of values between 6 and 9. The study also revealed that the karst water in Lusaka's Chainda is high in nitrates due to lack of sanitation facilities. Nitrates concentration were above the Zambian Bureau of Standards of $10 \mathrm{mg} / \mathrm{l}$ in all the shallow 
wells and private boreholes. While nitrate concentrations in water kiosks of LWSC are below ZABS. The shallow wells and private boreholes showed pollution from faecal bacteria (indicated by the Total Coliform concentration) was considerably higher with all of shallow wells and private boreholes exceeding the limit given in the Zambian Drinking Water Standard.

\section{References}

1. P. Williams, World Heritage Caves and Karst A Thematic Study. A global review of karst World Heritage properties: present situation, future prospects and management requirements (IUCN Programme on Protected Areas, Gland, Switzerland, 2008).

2. M. Petrič, Acta carsologica, 33(1), 12-24, (2004)

3. F. Gutiérrez, M. Parise, J. De Waele, H. Jourde, Earth-Science Reviewsб 138, 61-88, (2014)

4. S. E. Mazina, A.V. Gopin, A. L. Nikolaev, Water Resources, 36(6), 699-705 (2009)

5. T. Pipan, D. C. Culver, Int. J. Speleol., 42(3), 215-223 (2013)

6. J. De Waele, Environmental Geology, 58, 239-255 (2008)

7. Mpamba, et al., Data acquisition models for groundwater assessment and management in the urban and rural areas of Zambia.- Thesis (University of Zambia, School of Mines - Department of Geology, Lusaka, (2008).

8. R. Bäumle, J. Anscombe, C. Siwale, A. Nick, Development of a Groundwater Information \& Management Program for the Lusaka Groundwater Systems, Technical Note No. 8, Results of Drilling and Test Pumping at Three Selected Sites in Lusaka, Kafue and Chibombo Districts. (Ministry of Energy and Water Development Department of Water Affairs and Federal Institute for Geosciences and Natural Resources, Lusaka, 2012)

9. J. Gunn, Encyclopedia of Caves and Karst Science (Fitzroy Dearborn, New York, 2004).

10. J. De Waele, R. Follesa, Int. J. Speleol., 32(1/4), 71-83, (2003)

11. D. C. W. Nkhuwa, Materials and Geoenvironment. 50(1), 273-276, (2003)

12. M. Manafi, M. L. Rotter, Int. J. Food Microbiol. 14, 127-134. (1991) 